\title{
EDITORIAL
}

\section{Para incentivar a Ciência}

Considerando minha experiência como coordenadora da Residência Médica, na Secretaria do Estado da Saúde de São Paulo - instância da qual participo há mais de 30 anos -, bem como minha ênfase ao olhar em direção à Educação Médica, só poderia me orgulhar pelo fato de a Casa a qual presido lançar sua primeira revista científica, destinada, em essência, ao médico em início de carreira: a Journal of Medical Resident Research (JMRR).

Derivada de profícua publicação assumida no passado pelo Conselho Regional de Medicina do Paraná (CRM-PR) e, depois, pela Associação Nacional dos Médicos Residentes (ANMR), a JMRR aceita e estimula manuscritos de todos os colegas dispostos a acrescentar conhecimento e experiência acadêmica à nossa profissão, nos âmbitos técnico, ético, bioético e deontológico. Por outro lado, privilegia médicos em formação, sem o preconceito de pensar que a falta de experiência significa ausência de conteúdo, já que esses nos brindam com entusiasmo e pontos de vista arrojados, tão típicos da fase.

Nesta primeira edição, por exemplo, entre outros manuscritos, são observados os esforços de grupos que, em uma frente, buscam entender a motivação de seus pares em aderir a uma Liga Acadêmica, adotada hoje como atividade complementar no curso de Medicina. Em outra, decifrar os meandros da ideação suicida em meio a estudantes, assunto sério a ser entendido e enfrentado. Para dar uma ideia, na amostra de participantes dessa pesquisa, quase $22 \%$ apresentavam o risco de tirar a própria vida.

Ao lidar com temas assim, e, ainda, implantar um novo conceito de publicação no Cremesp, característico de ambientes universitários e de pós-graduação, o Conselho assumiu o grande desafio de adentrar no mundo da editoria científica, que é mantido vivo por dedicados pesquisadores e revisores, sem os quais não se faz Ciência de qualidade em lugar nenhum.

Não é um caminho simples, pois conta com especificidade e profundidade diferentes da vivenciada no dia-a-dia da - não menos relevante - assistência em consultório, hospital, PS, UTI, UBS e clínicas. Porém, enfrentar os desafios da pesquisa científica é algo imprescindível para viabilizar novas descobertas que, por sua vez, podem impactar justamente a prática clínica.

Sem dúvidas, o privilégio é deste Conselho de abraçar a ideia, apoiá-la e levá-la à frente, incentivando àqueles que têm interesse em compartilhar seus estudos a usarem esse meio que, se depender de dedicação, esmero, cuidado e vontade, em breve estará indexado nas melhores plataformas científicas.

Vamos aos trabalhos!

Irene Abramovich

Presidente do Cremesp

DOI: $10.5935 / 2763-602 X .20210008$ 